\title{
The Principle of Freedom of Contract, Pre-Contractual Obligations Legal Review English, EU and US Law
}

\author{
Tedoradze Irakli \\ Grigol Robakidze university PhD student
}

doi: 10.19044/esj.2017.v13n4p62 URL:http://dx.doi.org/10.19044/esj.2017.v13n4p62

\begin{abstract}
The impregnable foreign policy of Georgia is to become a full and equal member of the world. Over the past decade the country has been actively trying to integrate into the European economy, to regulate and harmonize the legal space, which will help the state to become attractive both for the world community, as well as potential investors and significantly strengthen its position in the domestic economy. A step forward in this direction may be considered signing the EU association agreement. This event clears the way to Europe for the business of Georgia. Therefore, it is extremely important to establish the proven regulations of Europe and to develop the legal space in compliance with international standards. All of this, of course, require legislative changes within the country in terms of its development, improving and adaptation, especially civil, antitrust, antidumping and competition regulatory legislation.
\end{abstract}

Keywords: Pre-contract, obligations, legal analyses, business environment, contractual autonomy

\section{Introduction}

Freedom of contract has been recognized as a 'general principle of civil law' by the European Court of Justice, ${ }^{13}$ (Europian Court 1999) has been seen as protected by article 16 of the EU Charter of Fundamental Rights ('freedom to conduct business') ${ }^{14}$ (EC Commission 2007) and has been set by the EU Commission as a fundamental point of reference for the future development of European contract law. ${ }^{15}$ (EC Commission 2005) Furthermore, a starting-point in freedom of contract or 'party autonomy' is

\footnotetext{
${ }^{13}$ Spain v Europian Commission, C-240/97 (Europian Court 1999).

${ }^{14}$ Commission, E. C. (2007 dec 14). Explanations relating to the Charter of Fundamental Rights OJ C 303.

${ }^{15}$ E.C. Commision . (2005). First Annual Progress Report on European Contract Law and the Acquis Review Com.
} 
reflected both in EU private international law ${ }^{16}$ (EPC 2008) and in EU substantive law provisions which qualify its application in the interests of protecting 'weaker parties' (notably consumers ${ }^{17}$ )(Brandner 1991) or which otherwise prohibit an 'abuse of freedom of contract'. As these latter examples make clear, however, in EU law as in the laws of the Member States, freedom of contract is no more than a starting-point (if an important one), given the range of modern social and political considerations which require its qualification. So, while the subordinate nature of the 'private law-making' of contracting parties has long been clearly proclaimed in national legal traditions, the last half century or so has seen a considerable growth in the range of 'public policy' qualifications on freedom of contract, notably for the protection of consumers, tenants and employees.

However, in my view, in modern European law (whether EU law proper or the laws of Member States) there lies under the banner of freedom of contract a fundamental duality of vision. On the one hand, freedom of contract can be seen as an economic principle on which markets of all kinds are to be based.

\section{Principle of freedom}

Seen in this light, the law's role in establishing or supporting freedom of contract lies in ensuring that legal and commercial institutions are so set up as o support a free and open market and, more specifically, the role of contract law is primarily (or at least generally) to support and facilitate market transactions: this may be termed 'the market vision' of freedom of contract. On the other hand, freedom of contract can instead be seen as a moral principle, according to which the justification for contractual obligations is found in the choice ('will') of the individuals party to the contract, a vision of freedom of contract often expressed on continental Europe under the phrase 'contractual autonomy' or 'the autonomy of the will' and with obvious roots in he philosophy of Rousseau and Kant: this may be termed the 'voluntarist' vision of freedom of contract. (J. Cartwright 2002)

The relationship between these different visions of freedom of contract is not straightforward either in the national laws of European Member States nor in EU law. So, rather than modern European laws fully reflecting one or other vision of the role of the law in relation to contracts (whether the general law or contract law properly so-called), these visions exist in tension within the laws, though to different extents in different substantive areas and in different national laws. So, while in some

\footnotetext{
${ }^{16}$ European Parlament and of the council . (2008). the law applicable to the contractual obligations "Rome I". regulation EC No 593/2008, (p. art 3).

${ }^{17}$ Brandner, H. E. (1991). Contractual Autonomy. Moscow: Spart.
} 
situations, these two visions of freedom of contract lead to the same approach to a particular legal issue (for example, as regards the general freedom whether or not to contract and with whom), in other situations they lead to very different approaches, different rules and different substantive results. For sometimes a concentration on the protection of an individual's 'will' may lead to a rule or rules which would not facilitate the reliable making of private transactions in the market. I will give no more than two examples from national laws.

First, English contract law possesses a very restricted law of vitiation of a contract on the ground of mistake: in principle, a single party's mistake ('unilateral mistake') is not a ground of invalidity and both the parties' mistake is only exceptionally a ground of invalidity: this position which sidelines the poor quality of a party's consent) is explicitly justified by the courts on the ground that it promotes certainty of contract, and this n turn reflects a concern that the law should be posited in a way which best facilitates private transactions. By contrast, the French law of mistake takes as its starting-point a concern with the quality of ('subjective' and therefore 'actual') consent of each of the contracting parties and this has end French courts to extend the narrowly drafted provisions of the Code civil so as to provide a broad ground of invalidity for error sur les qualités substantielles of the contract. (Ranouil V 1980)

Secondly, the modern laws controlling the effectiveness of 'unfair' contract terms can be seen differently according to the different visions of freedom of contract. So, these laws can be seen as qualifications on freedom of contract (and its sister principle of the binding force of contracts) in the interests of public policy or contractual justice: here, public policy trumps the general usefulness for the market of giving effect o contract terms, even to standard contract terms. Alternatively, or in addition, these modern laws can be seen as justified by the low quality or even lack of consent of one of the contracting parties, particularly where he term in question forms part of a standard form used by the other party $n$ the course of business: the control of unfair terms does not qualify the party's 'contractual autonomy', it seeks to protect it. Furthermore, sometimes the same vision of freedom of contract can lead to different approaches here. So, in English law the general position remains that in non-consumer contracts, terms (once agreed) are valid even if they are contained in a standard form of business of the other party: the use of standard form contracts (including onerous terms) is seen by most English lawyers as a legitimate expression of market power as well as of freedom of contract. By contrast, the modern German approach to the control of standard contract terms in all types of contracts (including $\mathrm{B} 2 \mathrm{~B}$ as well as B2C) is often justified on the ground that here there is a 
'partial failure of the market which may legitimately be corrected by means of judicial intervention'. ${ }^{18}$ (Zimmermann 2005).

The idea is that in B2B contracts businesses act rationally in relation to another business's standard contract terms by avoiding disproportionate costs of negotiating or obtaining the necessary information or contracts on more favorable terms given that these costs are out of proportion to the advantages to be gained. (H. kotz 1997) Here, therefore, a specifically market-oriented argument is used to justify legal intervention in market practices. Freedom of contract (market vision) can justify legal intervention.

However, in my view, the fundamental duality of vision of the principle of freedom of contract (market and voluntarist) can also be seen in EU law itself. The market vision can easily be seen in the most fundamental aspects of the law (notably, the fundamental freedoms guaranteed by the Treaty which are concerned to establish and to promote the internal market) and references to the needs of the internal market are prominent in EU secondary legislation governing contracts, reflecting the competences on which it is based.

However, on turning to the substance of a good deal of the same legislation, we find a clear concern with the quality of consent of contracting parties. This is particularly striking in the consumer acquits. So, for example, the Unfair Terms in Consumer Contracts Directive of 1993 starts by justifying its enactment by reference to 'the aim of progressively establishing the internal market' and that: the laws of Member States relating to the terms of contract between the seller of goods or supplier of services, on the one hand, and the consumer of them, on the other hand, show many disparities, with the result that the national markets for the sale of goods and services to consumers differ from each other and that distortions of competition may arise amongst the sellers and suppliers, notably when they sell and supply in other Member States. (directive 93/13/EEC) So, the Directive is needed so as to facilitate the conclusion of contracts within the European internal market (so fulfilling the condition in the EEC Treaty). On the other hand, on turning to the provisions of the Directive itself, these combine a concern with the substantive effect of a term allegedly unfair with a concern as to whether or not it is 'plain and intelligible'. The requirement of the with the transparency of contract terms reflects a concern with the quality of consent of a consumer to the particular term, even where it has not been individually negotiated.

In the western world, freedom of contract is one of the axioms of contract law. This means that parties are free to enter or not to enter into

18 Zimmermann, R. (2005). The new German Law of Obligations, Historical and Comparative Perspective. 
agreements. In former days agreement was based on a very classic as simple model: an agreement is reached at the moment that an offer is accepted and that is all.

However, times are changing. The classic procedure for entering into agreements does not meet the requirements posed by the market today anymore. The modern contract making process is often a set of very complex agreements and usually involves big amounts of money. The negotiations may last for months or even years. As a result, the parties will reach an agreement by piecemeal.

In this article I will discuss a very controversial topic in the theory of the formation of contracts: the relationship between parties in a situation in which an agreement has not been reached and one of the parties breaks off the negotiations. This can be done in several ways: one can just end the negotiations and walk away, the offerer can revoke his offer, an option clause is violated etc. Since there is still no contractual liability in these cases, the question arises if there is any liability at all and if so according to what theory a party is held liable.

I will analyze this problem from the point of view of two legal families: Common Law and Civil Law. In the context of this paper by Civil Law I mean the codified law systems in Western Europe and I will discuss French, German and Dutch law. We will see that there are important differences between the Common Law and the Civil Law approach to these problems. As a result of the still growing trade market between the United States and Western Europe it is of utmost importance that one is aware of these differences.

I want to discuss three topics:

1. cross-boundary pre-contractual negotiations will bring together law and culture and reality and perception and so many problematic situations; I will give you just some examples to show what I mean;

2. then I will discuss the different approaches as mentioned above and even more important the different results on what is understand as precontractual liability;

3. the last topic will be on recent European developments in contract law in this field as realized in a proposed European Code of Contract Law.

There is not a simple offer and an acceptance anymore, but there are offers, counteroffers, partial agreements etc. etc. and the ultimate agreement is reached only at the end of the discussion. But when exactly the discussion is ended? For this still developing contract formation procedure, in most legal systems there are no special and adequate rules established.

Since it is impossible to qualify in these cases offer and acceptance, a whole set of new problems arises:

1. has the agreement been concluded; 
2. when was it concluded;

3. if the agreement is concluded, what are the terms of it.

\section{Pre-ontractual liability in different legal systems}

For a long time the law remained completely silent as to the procedure for contract formation through negotiations. In former days the only requirements were offer and acceptance: when the offer is accepted the agreement has been reached, as simple as that. This approach was based on the so called aleatory theory of the pre-contractual process, which means that each party bears its own risks associated with the negotiation: both benefits and losses are treated as being at risk in negotiations.

This classical procedure theory is built on three assumptions:

1. any interference will result in the violation of the freedom of contract principle;

2. any interference will make the parties think twice before embarking on negotiations;

3. unless the parties are bound by an enforceable agreement, their behavior should be ignored as legally indifferent.

However, nowadays modern contract law recognizes negotiations as a separate contract formation procedure. A balance has to be found between freedom of contract and the protection of rights and interests of the parties entering in negotiations. Because it is almost impossible to work out detailed provisions, only general principles of pre-contractual behavior can be established. First I will take a short look at the Common Law approach and then I will discuss several Civil Law systems.

\section{English law}

(Giliker 2002, Cheshire and Fifoot 2001, Allen 1991)

In the case William Lacey (Hounslow) Ltd. V. Davis [1957] 1 W.L.R. 932, 934 (Q.B. 1957) the view is expressed that a party to negotiations '... undertakes this work as a gamble, and its cost is part of the overhead expense of his business which he hopes will be met out of the profits of such contracts as are made.' More recently the leading case on this topic is Walford v. Miles [1992] 1 All ER 453. The question was if the parties can, by agreement, impose on themselves a duty to negotiate in good faith. Lord Ackner held:

'Each party to the negotiations is entitled to pursue his (or her) own interest, so long as he avoids making misrepresentations. To advance that interest he must be entitled, if he thinks it appropriate, to threaten to withdraw from further negotiation or to withdraw in fact in the hope that the opposite party may seek to reopen negotiations by offering him improved terms.... A duty to negotiate in good faith is as unworkable 
in practice as it is inherently inconsistent with the position of the negotiating party.'

In spite of this rather rigid and formalistic view English law has taken on this question, there are some grounds to pursue negotiations or to recover damages in case of breaking off the negotiations.

Although the main contract has not been concluded, the court may held that there is a collateral contract which gives rise to some rights during the negotiating process.

And even though there is no contract, a party may be entitled to restitution relief on the grounds that the other party has derived a benefit from the transaction for which he should compensate the plaintiff even $\mathrm{f}$ no contract has arisen (unjust enrichment).

Finally a party can be held liable for loss which he inflicted on the other party in case of fraudulent misrepresentation (a claim in tort, e.g. when there was never an intention to form a contract) or negligent misrepresentation. In England one can only claim negative interests. Specific performance - that is to say forcing parties to re-open negotiations is not possible.

\section{American law}

(Tanner and Hamilton, paper 2004, Turack 1991)

Like in English contract theory, it is generally agreed that also in the United States the existence of a duty in good faith is denied in the absence of an enforceable contract. According to American law there are three other grounds for pre-contractual liability.

As in England, unjust enrichment as a basis for liability could be a ground for restitution. However, just a few courts have entertained such claims and the prevailing view is still the aleatory theory: both benefit and loss are at risk of the parties. Also the misrepresentation theory is considered to be a ground for recovering losses in the pre-contractual stage in the United States, but situations in which this occurs are quite rare.

The most fruitful basis for recovering pre-contractual damages in American courts is the doctrine of promissory estoppels: one negotiating party cannot without liability breach a promise made during negotiations, if the other party relied on that promise. Leading case is Hofmann v. Red Owl Store (133 N.W. 2d 267 (Wis. 1965)):

'[A] supermarket chain promised to sell the claimant a franchise, first advising the claimant to sell his bakery, move to another town and open a smaller grocery store as a means of gaining experience, and buy a lot the chain had selected for the potential franchise location. The supermarket chain then told the claimant to sell his small grocery store, which was operating at a profit, 
only to break off negotiations for the franchise shortly thereafter.' (Tanner 2004, p. 16)

The court formulates three requirements of promissory estoppels:

1. Was the promise one which the promissory should reasonably expect to induce action or forbearance of a definite and substantial character on the part of the promise?

2. Did the promise induce such action or forbearance/

3. Can injustice be avoided only by enforcement of the promise?

Than the court held:

'We deem it would be a mistake to regard an action grounded on promissory estoppels as the equivalent of a breach-of-contract action. As Dean Boyer points out, it is desirable that fluidity in the application of the concept be maintained. ... While the first two of the above listed three requirements of promissory estoppels present issues of fact which ordinarily will be resolved by a jury, the third requirement, that the remedy can only be invoke where necessary to avoid injustice, is one that involves a policy decision by the court. Such a policy decision necessarily embraces an element of discretion. We conclude that injustice would result here if plaintiffs were not granted some relief because of the failure of the defendants to keep their promises which induce plaintiffs to act to their detriment.'

Under the doctrine of promissory estoppels only negative interests can be recovered, damages based on loss of profits is considered inappropriate because estoppels is not the equivalent of breach of contract. In respect of promissory estoppels American law differs from English law; in English law this doctrine in the context of pre-contractual liability is seldom used. Another difference is that when there is a binding agreement to agree, there is a general obligation of fair dealing attaches to deal. The same result can be reached by a Letter of Intend: a duty to negotiate in good faith is imposed on the parties when the language of the Letter makes this duty clear or when it may be implied by the court if the agreement is silent. In absence of any of the above mentioned conditions, the core premise of the aleatory view of contract adopted by American courts is that a party to precontractual negotiations, may break off the negotiations at any time and for any reason, including no reason at all, and face no liability. Recovery based on restitution is measured by the benefit of the party which improperly received the idea of services. The measure of damages for misrepresentation is reliance interest, expectation interest and lost opportunities. The same is true for pre-contractual liability grounded upon the doctrine of promissory estoppels. No case law is available as to the question if an American court 
would order specific performance of either continued negotiations or of entering the envisaged contract. The overall view is, that specific performance might not be a realistic sanction in case of a breach of the obligation to negotiate, because the possibility of success in a forced negotiation will be quite slim. It is most likely that in a pre-contractual situation reliance damages are granted.

\section{Conclusion}

Up until now English courts have refused to regulate the precontractual period, save in exceptional circumstances. The most important tool seems to be the theory of unjust enrichment. In American law emphasis is on the theory of promissory estoppels as an explanation of pre- contractual liability. In my opinion the American approach is far more fruitful and satisfying then the English, because estoppel can be applied in far more cases then unjust enrichment and is - as an equitable remedy - more flexible.

\section{Pre-contractual liability in the principles of european contract law}

In the Introduction to the Principles of European Contract Law one can read:

'In some respects the Principles may be compared with the American Restatement of the Law of Contract, which was published in its second edition in 1981.Like the Restatements the articles drafted are supplied with comments and notes. The Restatements consist of non-binding rules, "soft law". They purport to restate the Common Law of the United States. The Principles are also "soft law", but their main purpose is to serve as a first draft of a part of a European Civil Code. Furthermore a common law does not to exist in the European Union. The Principles has therefore been established by a more radical process. No single legal system has been their basis. The Commission has paid attention to all the systems of the Member States, but not every of them has had influence on every issue dealt with. The rules of the legal systems outside of the Communities have also been considered. So have the American Restatement on the Law of Contracts and the existing conventions, such as The United Nations Convention on Contracts for the International Sales of Goods (CISG). Some of the Principles reflect ideas which have not yet materialized in the law of any state. In short, the Commission has tried to establish those principles which it believed to be best under the existing economic and social conditions in Europe.' 
Section 3 of the Principles is on liability for negotiations. Article 2:301 reads:

\section{Negotiations Contrary to Good Faith}

(1) A party is free to negotiate and is not liable for failure to reach an agreement.

(2) However, a party who has negotiated or broken off negotiations contrary to good faith and fair dealing is liable for the losses caused to the other party.

(3) It is contrary to good faith and fair dealing, in particular, for a party to enter into or continue negotiations ith no real intention of reaching an agreement with the other party.

This article may be assumed as a summary of Civil Law on the liability of breaking of negotiations.

\section{Conclusion on the civil law approach in comparison with the common law}

In the Common Law pre-contractual liability is imposed and based upon specific contract theories as restitution, misrepresentation and promissory estoppels. In Civil Law there are many ways to incorporate a duty of acting in good faith in the pre-contractual stage. In France it is based on tort law, in Germany on the doctrine of culpa in contrahendo - which seems to be an extension of contract law - and now codified in the Civil Code and in The Netherlands on tort law or on pre-contractual good faith as a standard on its own. Except for the Netherlands, in all other legal systems in this research one cannot recover but for negative interests. The Dutch legal system goes two steps further:

- one can recover positive damages as well;

- the court can force a party to re-open the negotiations.

The overall conclusion is, that there are substantial more possibilities to recover damages in cases of pre- contractual liability in the codified law systems discussed above, than in Common-law countries.

\section{References:}

1. Brandner, H. E. (1991). Contractual Autonomy . Moscow: Spart.

2. Cartwright, J. (2002). Defects of Conset and Security of Contract: Franch and English Law compared. oxford: OUP.

3. Commission, E. C. (2007 dec 14). Explanations relating to the Charter of Fundamental Rights OJ C 303.

4. E.C. Commision . (2005). First Annual Progress Report on European Contract Law and the Acquis Review Com. 
5. Eropean Parlament and of the Council. (2000). combating late payments in commercial transaction.

6. European Parlament and of the council . (2008). the law applicable to the contractual obligations "Rome I". regulation EC No 593/2008, (p. art 3).

7. kotz H, \& fleesner, A. (1997). European Contract Law. oxford.

8. Spain v Europian Commission, C-240/97 (Europian Court 1999).

9. Veronique, R. (1980). L'autonomie de la volonte, Naissance et evolution d'un concept. Paris: PUF.

10. Zimmermann, R. (2005). The new German Law of Obligations, Historical and Comparative Perspective. 